\title{
Economic policies for tobacco control in developing countries
}

\author{
Ross H, (1) Chaloupka FJ.(2)
}

\section{Ross H, Chaloupka FJ. \\ Economic Policies for tobacco control in developing Countries. Salud Publica Mex 2006;48 suppI I:SI I3-SI 20.}

\begin{abstract}
Raising tobacco taxes can have an income distributional impact on the population. Since lower socio-economic groups usually smoke more, they also contribute more to total cigarette tax collection. Thus, those who can afford it least contribute the most in terms of tobacco taxes. This means that tobacco taxes are regressive. However, tobacco tax increases are likely to be progressive, decreasing the relative tax incidence on the poor, vis-à-vis the rich. This is based on the premise that the poor are likely to be more sensitive to price changes, and would thus reduce their cigarette consumption by a greater percentage than the rich in response to an excise tax-induced increase in cigarette prices. Recent empirical studies confirm this hypothesis by demonstrating that the price responsiveness of cigarette demand increases with income. Research in China confirmed that reducing cigarette expenditures could release household resources for spending on food, housing, and other goods that improve living standards. Therefore, in the long run, tobacco control measures will reduce social inequality.
\end{abstract}

Key words: economic policy; tobacco; control; taxes
Ross H, Chaloupka FJ.

Política económica para el control

del tabaco en países en vías de desarrollo.

Salud Publica Mex 2006;48 supl I:SI I3-SI 20.

\section{Resumen}

Elevar impuestos al tabaco también puede provocar en la población un impacto de división. La recaudación de impuestos al tabaco se ha elevado desde que las personas de bajo nivel socio-económico fuman cada vez más y, de hecho, son los que más contribuyen al total de la recaudación. Esto significa que los impuestos son regresivos. Sin embargo, el impuesto al tabaco es probable que vaya en aumento, y con ello disminuiría la incidencia relativa de impuestos a la pobreza en relación con la riqueza. Esto se basa en la premisa de que la población de escasos recursos es más sensible a los cambios del precio del tabaco y, por tanto, reduciría su consumo, en comparación con lo que sucede en el porcentaje de la población de altos recursos respecto a un aumento del impuesto-inducido en el tabaco. Los estudios empíricos recientes confirman esta hipótesis y demuestran que el precio del cigarrillo experimenta un aumento con las ganancias. La investigación en China ratifica que reduciendo el consumo de cigarros se podrían ingresar mayores recursos para alimentación y sustento a las familias, así como otros productos que ayuden a incrementar su nivel de vida. Por lo tanto, a largo plazo, las medidas para el control de tabaco reducirían la inequidad social.

Palabras clave: política económica; tabaco; control; impuestos
$\mathrm{T}$ obacco consumption is one of the 10 leading risk factors threatening health globally; together, these 10 factors account for more than one-third of all deaths worldwide. In 2000, tobacco use was the second major cause of death in the world, accounting for about five million premature deaths. The death toll from tobacco is expected to double in the next 20 years. There are currently 1.3 billion smokers in the world and this number will increase to 1.7 billion by 2025 if no action is taken to curb the prevalence of tobacco consumption. ${ }^{1}$

(I) International Research Triangle Institute. North Carolina, USA.

(2) Department of Economics. University of Illinois at Chicago, USA.

Accepted on: February 15, 2006

Address reprint request to: Frank J. Chaloupka. Institute for Health Research and Policy (m/c 275).

University of Illinois at Chicago, 1747 West Roosevelt Blvd., Room 558, 60608. Chicago, IL, USA. E-mail: fjc@uic.edu 
This trend is a concern not only because of the millions of deaths and related suffering that it involves, but also due to the substantial health care, lost productivity and other social costs that result and, in developing countries, because of its negative impact on economic development. Thus, regulating tobacco consumption can be viewed as a component of economic policy. Governments in many countries of the world have committed themselves to reducing the negative impact of tobacco consumption by ratifying the Framework Convention on Tobacco Control, an international legal instrument adopted in May 2003 by the World Health Assembly.

\section{Rationale for government intervention}

Government interventions in tobacco markets can be justified by the existence of market failures, including the presence of externalities in tobacco consumption and the imperfect information about the risk from tobacco use. These economic inefficiencies arise due to risks imposed on non-smokers, on children and on adult smokers who are not well-informed about the health and addictive consequences of tobacco consumption. ${ }^{2,3,4}$ Studies show that the vast majority of smokers regret that they ever started to smoke, ${ }^{5}$ and that a large proportion, even of young smokers, want to quit. ${ }^{6}$

In addition, tobacco use imposes financial costs on national health systems and the population. ${ }^{7}$ The World Bank estimates that the overall annual cost of healthcare attributable to tobacco use is between 6 and $15 \%$ of total healthcare costs in high-income countries. ${ }^{2}$ In many countries, costs of treating tobacco-related diseases are covered by public funds. In Mexico, for example, preliminary estimates indicate that about $1 \%$ of the total health care budget for the state of Morelos, or $\$ 1.7$ million dollars per year, is devoted to treating tobacco-related diseases.

Tobacco consumption is also a significant contributor to poverty in low-income countries. The burden of disease associated with tobacco use is increasingly borne by the poor and uneducated, as they are more likely to use tobacco. ${ }^{8}$ In addition, tobacco expenditures can have serious implications for the welfare of poor families by diverting scarce resources from food and other necessities. In 2001, the lowest income families in Nepal and in Myanmar spent as much as $9.6 \%{ }^{9}$ and $4.0 \%{ }^{10}$ of their household budgets on tobacco products. The poorest Mexican families spend from 9 to $22 \%$ of their income on tobacco. ${ }^{11,12}$

The negative health and economic consequences of tobacco use are detrimental to overall economic development. ${ }^{1}$ Tobacco-related diseases have a negative impact on labor productivity. Half of the people killed by tobacco-related diseases die during their active working life, which greatly affects those family members who are dependent on their income. ${ }^{2}$ Their deaths also deprive society of their contributions as workers and parents. ${ }^{1}$ The European Commission (EC) has specifically recognized tobacco as a development issue, since its production and consumption lead to poverty and undermine sustainable development. ${ }^{13}$ The WHO Commission on Macroeconomics and Health (CMH), established in 2000, also recognized tobacco as a major risk factor for all developing countries because of its negative impact on their economic development. ${ }^{14}$ Thus, reducing tobacco use would help achieve the UN Millennium Development Goals of reducing poverty, disease, hunger, and environmental degradation. Economic measures to reduce tobacco use that are part of a comprehensive tobacco control program can reduce the negative impact of smoking.

\section{Effective interventions}

Studies in both low- and high-income countries confirm that tax increases are a highly effective and practical way to correct economic inefficiencies in tobacco product markets. Higher tobacco taxes, passed on to consumers in the form of higher cigarette and other tobacco product prices, reduce overall consumption of tobacco products. This reduction is achieved via several behavioral responses: cessation among existing users, prevention of initiation (and re-initiation) among potential users, and reduction in the intensity of use among continuing users.

The estimates of the impact of price on cigarette demand fall in a relatively wide range depending on the population studied, the data employed, and the methods used to estimate demand..$^{15,16}$ The majority of the evidence, based on studies of populations living in developed countries, suggests that a $10 \%$ increase in cigarette prices would result in a 2.5 to $5 \%$ reduction in cigarette demand. ${ }^{17}$

Estimates of the price responsiveness of populations living in low- and middle-income countries have become available only recently, as the changing pattern in global tobacco consumption and its implication for global health and the global economy have motivated economic research into smoking behavior in those countries. These emerging studies suggest that the impact of price on tobacco use in low- and middleincome countries is at least as large, and likely larger, than its impact in high-income countries.,18

\section{Impact of Cigarette Prices on Cigarette Demand}

Tobacco demand in low- and middle-income countries has been studied primarily by analyzing national-level aggregate consumption data (generally based on paid 
sales tax) and individual or household-level survey data. The macro-level estimates assess the impact of price and income on the overall demand for tobacco in the entire country. This approach was used in several studies in Latin American countries. For example, a 1998 study from Brazil used annual data on cigarette consumption for the period 1983 to 1994 and found that a 10\% increase in cigarette prices would reduce overall cigarette consumption up to $2 \%$ in the short-run, and up to $8 \%$ in the long-run. ${ }^{19}$ The same study also found that a $10 \%$ rise in income would increase cigarette consumption in Brazil up to 3.1\% in the short-run and up to $8 \%$ in the long-run. Similarly, annual data from 1970 to 2000 were employed in a 2001 study from Venezuela that found that price has a significant and negative impact on cigarette consumption: a 10\% price increase would lead up to a $3.6 \%$ reduction in overall cigarette demand; a $10 \%$ higher income would increase the cigarette demand by 12 to $22 \%$ **

Macro-level evidence on price responsiveness is now also available from several low-income Asian countries. The 2002 estimates for China, based on economic models of addiction and using data from 1980 to 1996, concluded that a $10 \%$ increase in cigarette prices would decrease cigarette consumption by up to $5.4 \%$ in the short-run and by up to $6.6 \%$ in the long-run. ${ }^{20} \mathrm{~A} 2002$ study from Indonesia used time series data and estimated the impact of cigarette prices and income on the total demand for cigarettes. ${ }^{21}$ The authors found that price had a negative and significant impact on cigarette consumption, while higher income increased cigarette consumption: a $10 \%$ increase in real cigarette prices lowered the demand by 3.2 to $5.7 \%$, and a $10 \%$ increase in real income increased this demand by about $4.7 \%$. The degree of price responsiveness was larger when the yearly data were used, compared to the results based on monthly data. This difference was attributed to the longtime, addicted smokers' need to adjust their behavior to new prices. Substitution between tobacco products was not considered in this study, which can lead to overestimating consumers' responsiveness in that some smokers may substitute other tobacco products when cigarette prices rise. Research in Sri Lanka evaluated aggregate monthly data on cigarette consumption from 1999 to 2000 and concluded that a $10 \%$ increase in cigarette prices would reduce overall consumption by 2.3 to $9.1 \%$; a $10 \%$ increase in income would increase overall cigarette consumption by 1.8 to $7.8 \% .^{22}$ This wide range of estimates was due to the use of various tobac-

\footnotetext{
* Gabaldon G, Herrera N. Economic assessment of public policies for tobacco control in Venezuela, 2001. Unpublished.
}

co demand model specifications. However, price and income were significant determinants of tobacco demand in each of the models.

A recent regional study pooled together macro-level data (1970 to 2000) from several South East Asian countries (Bangladesh, Indonesia, Nepal, Sri Lanka, and Thailand) to estimate both conventional and myopic addiction cigarette demand in the area. ${ }^{23}$ The conventional model estimated that a 10\% increase in cigarette prices would decrease overall consumption of cigarette in the region by 6 to $9 \%$. The myopic addiction models showed that the short-term impact of a 10\% increase in cigarette prices would lower overall cigarette consumption by 1 to $7.8 \%$, but the long-term impact would reduce this consumption by 4 to $14 \%$; a $10 \%$ increase in income would increase cigarette consumption in the region by 2.8 to $17 \%$.

These macro-level studies provide information on the overall responsiveness of populations to economic incentives in the tobacco market, but they cannot distinguish between the impact of higher cigarette price on smoking cessation, smoking initiation, and smoking intensity. In addition, most of these studies do not account for possible smuggling and tax avoidance, home tobacco production, or substitution of other tobacco products. The use of individual or household-level survey data allows the separation of the impact of higher prices and other tobacco control measures on smoking prevalence and smoking intensity, the analysis of cigarette demand in various population subgroups, potential tax avoidance behaviors, and substitution among tobacco products.

The Mexican National Household Income and Spending Survey data 1989-1998 allowed the estimation of price and income responsiveness among various income groups of the population. ${ }^{24}$ Results demonstrate that a price increase of $10 \%$ will reduce tobacco consumption by $1.1 \%$ in the short-run, and by $7.3 \%$ in the long-run, independent of the income group. In addition, a 10\% increase in tobacco taxes would increase government revenues by $5.7 \%$. A second study from Mexico confirmed these results by employing four cross sectional data from 1992 to $1998 .{ }^{11}$ It found that cigarette prices were the most important determinant of cigarette spending and that income was positively related to cigarette spending.

Numerous recent studies conducted in Asian countries provide additional proof of the price and income responsiveness of populations living in low- and middle-income countries. Household data from the 1999 Indonesia national socio-economic survey were used to estimate the impact of cigarette prices and income on cigarette demand. ${ }^{25}$ Cigarette prices were not found to significantly impact the household decision to consume cigarettes, but they reduced the number of cigarettes consumed by a household: a 10\% increase in cigarette 
prices reduced cigarette consumption by $6 \%$. The finding that cigarette prices do not effect the decision to smoke is contrary to other research in the region and is related to the model specification, which measured the price variation based on cigarette type preferences (taste preferences) as opposed to the real price variation based on regional differences in cigarette prices. The study further finds that income is positively associated with spending on tobacco products: a $10 \%$ increase in real income increases cigarette consumption by $7.6 \%$. The response to cigarette prices and to income change is greater among lower income groups.

A 2003 study used household data from the 2000 Nepal smoking behavior survey to estimate price and income responsiveness of the local population. ${ }^{9}$ The study found that a $10 \%$ increase in cigarette prices would reduce the cigarette consumption by $8.8 \%$. About half of this impact was due to a decrease in the smoking rate and half due to a reduction in smoking intensity among current smokers. Price responsiveness was higher among the youngest age groups and among the lowest income groups. The estimated sensitivity of cigarette demand to income was rather low: a 10\% increase in income would increase the overall demand for cigarettes by $1.8 \%$, mostly due to a $1.1 \%$ increase of consumption among the current smokers. The impact of income on smoking initiation was not significant.

A group of researchers from Thailand used household level data from a 2000 Thailand socioeconomic survey to estimate a linear expenditure system model. ${ }^{27}$ They found that a $10 \%$ increase in cigarette prices would result in a 3.9\% decline in overall cigarette consumption and that a $10 \%$ increase in income increases cigarette consumption by $7 \%$. As seen in studies from high-income countries, smoking among low-income groups, young people, and those living in urban areas was found to be more responsive to changes in cigarette prices than was smoking in higher income groups, older persons, and those living in more rural areas.

An analysis of the 2000 household survey from Myanmar concluded that a $10 \%$ increase in cigarette prices would lead to a $12.8 \%$ decline in smoking prevalence and a $3.4 \%$ lower smoking intensity among continuing smokers, ${ }^{26}$ relatively high estimates compared to other countries in the region. The price responsiveness was highest among the youngest age groups, but there was no difference in people's responsiveness according to income categories. Unlike the results from Thailand, ${ }^{27}$ this research found households living in rural areas to be more price sensitive than households living in urban areas. The study did not find any evidence of sensitivity of cigarette demand to income.
Contrary to the findings from Myanmar, a 2002 study of the responsiveness of Chinese and Russian populations to cigarette prices found that it is relatively small. ${ }^{28}$ For China, it employed household panel data based on surveys in 1993 and 1997, and for Russia, it used longitudinal data from eight rounds of household surveys conducted between 1992 and 2000. The model estimated the impact of higher cigarette prices on smoking participation and smoking intensity, controlling for age, wealth, education, household size, and gender. In China, a 10\% increase in cigarette prices would reduce overall cigarette consumption by 0.2 to $1.1 \%$, but it would reduce smoking participation by less than $0.5 \%$. In Russia, a similar price change would reduce the overall cigarette consumption by 0.2 to $1.8 \%$ and reduce smoking participation by 0.5 to $1 \%$.

A 2002 study from Bulgaria utilized a household survey to estimate the impact of cigarette prices and income on cigarette consumption, controlling for a wide range of factors such as the mean age of the household, the number of years of education received by the most educated household member, the amount of alcohol consumed per capita in each household, and the ratio of the number of adult males in each household to the size of the household. ${ }^{9}$ The study found that the lowand middle-income groups were more price sensitive, decreasing their cigarette consumption by $13.3 \%$ in response to a $10 \%$ cigarette price increase. The high-income group responded to the same price change by reducing its consumption by $5.2 \%$; a $10 \%$ increase in income would lead to a $3.4 \%$ higher cigarette demand.

The evidence from South Africa using household data on income and expenditure (1990 to 1995) also suggests rather high responsiveness of the population to cigarette prices: a 10\% increase in cigarette prices would reduce the overall demand for cigarettes by 8.1 to $13.9 \%$, with the lowest income groups being at the higher end of the estimate. ${ }^{30}$ The study found a slightly higher impact of income in 1995 compared to 1990: a 10\% higher income would increase cigarette consumption by up to $4.8 \%$ in 1990 , and up to $5.2 \%$ in 1995 .

Although these country-specific studies on the impact of price on cigarette demand differ in their methods and datasets used, several consistent findings emerge. All studies find that higher cigarette prices reduce cigarette smoking. Short-run price responsiveness of the population living in developing countries suggests that a 10\% increase in cigarette prices would cause a 0.2 to $16.2 \%$ reduction of cigarette demand in the short run, with most estimates being in the range of 3.2 to $7.8 \%$. The same real price increase would produce larger reductions in smoking in the long-run, with estimates indicating that a 10\% sustained increase in cigarette prices would reduce ciga- 
rette consumption from 4 to $14 \%$. The results also show that price responsiveness is not homogenous across various population subgroups. The young and lower-income groups are the most price-responsive. Finally, this body of evidence suggests that income is positively related to tobacco consumption in the developing world, especially among poorer households.

\section{Impact of cigarette prices on initiation and cessation}

Relatively few studies in low- and middle-income countries have focused on the impact of cigarette prices on smoking cessation. A 2004 study of cigarette demand and demand for rustic tobacco in Vietnam used data from two rounds of the Vietnam Living Standards Survey: in 1992-1993 and 1997-1998. ${ }^{31}$ They found a significant and negative impact of cigarette price on smoking initiation (a 10\% increase in cigarette price would reduce smoking initiation by $11.8 \%$ ). However, the study did not find a significant impact of higher cigarette prices on smoking cessation. There is evidence of substitution among tobacco products in response to changes in relative prices. The study concluded that higher cigarette prices may not necessarily encourage quitting and may only divert cigarette smokers to rustic tobacco, which may be as harmful to health as are cigarettes.

The majority of studies of youth smoking prevalence and youth initiation in low- and middle-income countries are descriptive in nature, and assess the trends in tobacco consumption among new generations over time. Few studies evaluate the impact of economic measures on youth smoking behavior. A 1999 study from Brazil concluded that the price responsiveness of teenagers is twice as large as the price responsiveness among adults. ${ }^{32}$ The results indicate that a $10 \%$ increase in cigarette prices would lead to a $14 \%$ decline in cigarette consumption among Brazilian teenagers. However, the study did not distinguish between the impact of price on non-initiation and on smoking cessation. As discussed above, several studies estimating the price responsiveness of cigarette demand to cigarette prices found that young people are highly price-responsive compared to their older counterparts. However, further research is needed to separate the impact of higher cigarette prices on smoking prevalence into its components, impact on smoking cessation and on smoking initiation.

\section{Tobacco taxes and government revenues}

As described above, there is considerable evidence that higher tobacco taxes can improve public health by reducing tobacco use, resulting in reductions in tobacco-related morbidity and mortality. In addition, cigarette tax increases can also help a country by generating additional revenue and reducing expenditures on the treatment of tobacco-related diseases. To the extent that some of these additional revenues are dedicated to comprehensive tobacco control efforts, additional reductions in tobacco use and improvements in public health can result. ${ }^{18}$

A recent study conducted in South-East Asia documented the revenue-generating potential of tobacco taxes. ${ }^{22}$ Assuming that real GDP per capita in the region grows $4 \%$ annually, a 5\% increase in real cigarette prices induced by higher taxes would generate substantial additional revenue for the region by 2010. For example, such a tax would generate an extra \$8300 million dollars in Indonesia, \$4 750 million dollars in Thailand, \$994 million dollars in Bangladesh, \$725 million dollars in Sri Lanka, and \$440 million dollars in Nepal by 2010, compared to their revenue in 2000.

Determining optimal levels of taxation on cigarettes is complex and depends on a variety of factors, including revenue considerations, societal values, and what a society hopes to achieve through these taxes. A useful yardstick is the tax level adopted by high-income countries as part of comprehensive tobacco control policies. In 2000, taxes on tobacco products globally accounted for approximately $44 \%$ of the final retail price of tobacco products, which translates to a $79 \%$ mark-up on the pre-tax price. ${ }^{33}$ Cigarette taxes tend to be higher in wealthier places and where strong tobacco control programs exist, such as Norway, Australia, and Hong Kong. In many developing countries where tobacco control programs are not yet comprehensive, cigarette prices have decreased in last decade. ${ }^{31}$

Potential impact of higher taxes and other demand reduction measures

A simple static model using the cohort of smokers alive in 1995 predicted that tax increases that raise the real price of cigarettes by $10 \%$ worldwide would cause about 42

\section{Table I \\ Potential impact Of A PRICE INCREASE OF $10 \%$ AND A PACKAGE OF NON-PRICE MEASURES}

\begin{tabular}{lccccc} 
& \multicolumn{2}{c}{$\begin{array}{c}\text { Change in number } \\
\text { of smokers (millions) }\end{array}$} & & \multicolumn{2}{c}{$\begin{array}{c}\text { Change in number } \\
\text { of deaths (millions) }\end{array}$} \\
\cline { 2 - 3 } \cline { 5 - 6 } Region & $\begin{array}{c}\text { Price } \\
\text { increases }\end{array}$ & $\begin{array}{c}\text { Non-price } \\
\text { measures }\end{array}$ & $\begin{array}{c}\text { Price } \\
\text { increases }\end{array}$ & $\begin{array}{c}\text { Non-price } \\
\text { measures }\end{array}$ \\
Low/Middle Income & -38 & -19 & & -9 & -4 \\
\hline High Income & -4 & -4 & -1 & -1 \\
\hline World & -42 & -23 & -10 & -5
\end{tabular}

Source: Ranson et al, 2000. (Reference 16) 
million smokers to quit, preventing at least 10 million tobacco-related deaths. A combined set of non-price measures (such as comprehensive bans on advertising and promotion, bans on smoking in public places, prominent warning labels, and mass information) would lead to about 23 million people alive in 1995 to quit smoking, thus preventing five million deaths in this cohort. ${ }^{34}$ Table I shows that the impact of higher prices in low- and middle-income countries is expected to be much larger, compared to the impact in high-income countries.

Apart from taxes, other effective tobacco control measures include information campaigns, comprehensive bans on advertising and promotion, prominent warning labels, and clean indoor air restrictions. ${ }^{35,36}$ Using the same model, it has been predicted that a comprehensive approach to applying these measures would encourage about 23 million smokers alive in 1995 to quit, averting five million tobacco-related deaths over time. ${ }^{34}$ Even a smaller, but targeted mass media campaign has proved effective. Research in Mexico shows that 1853 smokers attempted to quit after an anti-smoking mass media campaign. The sale of nicotine patches significantly increased and 96 people per day successfully quit smoking after the campaign. ${ }^{37}$ The use of nicotine replacement therapies could persuade six million smokers alive in 1995 to quit and could avert one million deaths. ${ }^{34,38}$ All these interventions are cost-effective in comparison with many health interventions. ${ }^{39}$

In contrast to measures to reduce demand, most measures to reduce supply, including complete prohibition on tobacco products, restrictions on tobacco-related trade, crop substitution programs, and limits on youth access to tobacco products, are largely infeasible or ineffective. The key exception is strong action to reduce smuggling. Effective measures include prominent tax stamps and local language warning labels on cigarette packs, aggressive enforcement, and consistent application of strong penalties on smugglers.

\section{The economic costs and consequences of tobacco control}

Several concerns are often raised about the economic consequences that may result from strong tobacco control policies. For example, there is a fear that reduced consumption of tobacco products due to strong tobacco control efforts will cause permanent job losses. However, falling demand for tobacco does not necessarily mean falling employment. Money that smokers once spent on cigarettes would instead be spent on other goods and services, generating other jobs to replace any lost from the tobacco industry. Studies show that most countries would see no net job losses, and that a few would see net job gains, if tobacco consumption fell. ${ }^{39,40}$
Another concern is that higher tax rates will reduce cigarette consumption and therefore reduce government revenues. The experience of nearly all countries has been to the contrary; in the overwhelming majority of countries, increases in tobacco taxes result in both reductions in tobacco use and increases in tobacco tax revenues. ${ }^{41}$ In the very few exceptions to this, stronger policies to curb smuggling and tax evasion/avoidance could have produced the same effects. In Canada, for example, tobacco tax increases by federal and provincial governments in the early 2000s have led to significant declines in smoking while at the same time greatly increasing government revenue. ${ }^{42}$ A study from China suggests that a 10\% increase in cigarette tax would decrease consumption by $5 \%$ and increase tobacco tax revenue by $5 \%$. This additional income would be sufficient to finance a package of essential health services for one-third of China's poorest 100 million citizens. ${ }^{44}$ It is predicted that a global $10 \%$ increase in cigarette taxes would raise cigarette tax revenues by nearly $7 \%$ on average..$^{43}$

Cigarette smuggling is often cited as an argument against a tobacco tax increase. The claim is that increases in tobacco taxes will stimulate widespread smuggling of tobacco products and that smokers and other tobacco product users will engage in extensive efforts to avoid the higher taxes, thereby keeping tobacco consumption and its consequences high but reducing government revenues. Smuggling can be a serious problem. Estimates suggest that 6 to $8 \%$ of all cigarettes consumed globally are smuggled. ${ }^{44}$ However, there is little if any empirical support that links price differentials with increased smuggling. ${ }^{45}$ On the other hand, corruption inside a country and other factors are found to be stronger predictors of smuggling than is the level of tobacco product taxes and prices. ${ }^{44}$ Although most time series analyses do not control for the impact of smuggling on cigarette consumption, household level analyses implicitly control for smuggling as they are based on survey data that captures total consumption, whether purchased in the legal or black market. These studies confirm the negative impact of higher cigarette prices on household cigarette consumption. There is empirical evidence demonstrating that tax increases decrease consumption and increase government revenue in the short and medium term, even in the presence of cigarette smuggling. ${ }^{44,46}$

Higher tobacco taxes can also have an income distributional impact on the population. Since lower socioeconomic groups usually smoke more, they also contribute more to total cigarette tax collection. Thus those who can afford it least contribute the most in terms of tobacco taxes. This means that tobacco taxes are regressive. However, tobacco tax increases are likely to be progressive, decreasing the relative tax incidence on the poor, 
vis-à-vis the rich. This is based on the premise that the poor are likely to be more sensitive to price changes, and would thus reduce their cigarette consumption by a greater percentage than the rich in response to an excise taxinduced increase in cigarette prices. Recent empirical studies confirm this hypothesis by demonstrating that the price responsiveness of cigarette demand increases with income. ${ }^{18}$ Research in China confirmed that reducing cigarette expenditures could release household resources to spend on food, housing, and other goods that improve living standards. ${ }^{47}$

Therefore, in the long-run, tobacco control measures will reduce social inequality.

\section{References}

1. United Nations Economic and Social Council Ad hoc Inter-Agency Task Force on Tobacco Control Report of the Secretary-General. New York: UN, 2004.

2. Jha P, Chaloupka FJ. Curbing the epidemic: governments and the economics of tobacco control. Washington DC:World Bank, 1999. 3. Jha $P$, Musgrove $P$, Chaloupka FJ, Yurekli A. The economic rationale for intervention in the tobacco market. In: Jha P, Chaloupka FJ, eds. Tobacco control in developing countries. Oxford: Oxford University Press, 2000:153-174.

4. Warner KE, Chaloupka FJ, Cook PJ, Manning WG, Newhouse JP, Novotny TE, et al. Criteria for determining an optimal cigarette tax: the economist's perspective. Tob Control 1995; 4: 380-386.

5. Fong GT, Hammond D, Laux FL, Zanna MP, Cummings KM, Borland R, et al. The near-universal experience of regret among smokers in four countries: Findings from the International Tobacco Control Policy Evaluation Survey. Nicotine Tob Res 2004;6 suppl 3:S34I-S35I. 6. Martin JP, Peruga A. The global youth tobacco survey: Results in the Americas. Epidemiological Bulletin. PAHO 2002; 23(2).

7.Valdes-Salgado R, Hernandez-Avila M,Amor JS. Tobacco consumption in the Americas: Elements for an anti-smoking program. Salud Publica Mex 2002;44 Suppl I:SI25-I35.

8. Bobak M, Jha P, Nguyen S, Jarvis M. Poverty and smoking. In: Jha P, Chaloupka FJ, ed. Tobacco control in developing countries. Oxford: Oxford University Press, 2000: Ch3.

9. Karki YB, Pant KD, Pande BR. The economics of tobacco in Nepal. HNP Discussion Paper. Economics of Tobacco Control Paper No 13. Washington DC:World Bank, 2003.

10. Nyo Nyo K, Zaw KK, Naing KK. The economics of tobacco control in Myanmar. HNP Discussion Paper. Economics of Tobacco Control Paper No. I4. Washington DC:World Bank, 2003.

II. Sesma-Vazquez S, Campuzano-Rincon JC, Carreon-Rodriguez VG, Knaul F, Lopez-Antunano FJ, Hernandez-Avila M. El comportamiento de la demanda de tabaco en México: 1992-1998. Salud Publica Mex 2002;44 Suppl I:S82-92.

12.Vazquez-Segovia LA, Sesma-Vazquez S, Hernandez-Avila M. Tobacco use in Mexican households: Results of the income and expenses of households, 1984-2000. Salud Publica Mex 2002;44 Suppl I:S76-8I. 13. Tobacco Control and Development Policy. In: European Commission Roundtable 3-4 Brussels, Belgium: February 2003. Available in: http://europa.eu.int/comm/health/ph_determinants/life_style/Tobacco/ round_table_international_tobacco_en.htm
14. Macroeconomics and health: Investing in health for economic development. Report of the Commission on Macroeconomics and Health.WHO December 200I.Available in: http://www.cmhealth.org/ 15. Gallet CA, List JA. Cigarette demand: a meta-analysis of elasticities. Health Econ 2003; 12(I0):82I-35.

16.Wasserman J, Manning WG, Newhouse JP et al. The effects of excise taxes and regulations on cigarette smoking.J Health Econ 1991;10(I):43-64.

17. Chaloupka FJ,Warner KE. The economics of smoking. In: Newhouse, JP, Cuyler AJ ed. The handbook of health economics. New York: NorthHolland, 2000.

18. Chaloupka, FJ, Hu T, Warner LE, Jacobs R, Yurekli A. The taxation of tobacco products. In: Jha P, Chaloupka FJ. 2000: Ch 10.

19. Da Costa e Silva VL.The Brazilian cigarette industry: prospects for consumption reduction. In:Abedian I et al., eds. The economics of tobacco control: towards an optimal policy mix. Cape Town:Applied Fiscal Research Centre, University of Cape Town, 1998.

20. Hu TW, Mao Z. Effects of cigarette tax on cigarette consumption and the Chinese economy. Tob control 2002; II (2): 105-108.

21. Djutaharta T,Viriya-Surya H, Haidy N, Pasay A, Moertiningsih-Adioetomo $\mathrm{H}$, Moertiningsih-Adioetomo S.Aggregate analysis of the impact of cigarette tax rate increases on tobacco consumption and government revenue: The case of Indonesia. HNP Discussion Paper. Economics Of Tobacco Control Paper No. 25. Indonesia:World Bank, 2005.

22. Arunatilake N.An economic analysis of tobacco demand in Sri Lanka. Sri Lanka Economic Journal 2002; 3(I):96-I 20.

23. Guindon GE, Perucic AM, Boisclair D. Higher tobacco prices and taxes in South East Asia. HNP Discussion Paper, Economics of Tobacco Control Paper No.I I. Washington DC:World Bank, 2003.

24. Sesma-Velásquez S, Campuzano-Rincón JC, López-Antuñano FJ, Knaul F, Hernández-Avila M. Price as determinant of tobacco consumption in México. Poster presentation \#42697 at the 130th Annual Meeting of APHA. Philadelphia, EUA. 2002, November 12. 25. Moertiningsih Adioetomo S, Djutaharta T, Djutaharta H. Cigarette consumption, taxation and household income: Indonesia case study. World Bank Health, Nutrition and Population (HNP) Discussion Paper. Economics OfTobacco Control Paper No. 26. Indonesia:World Bank, 2005. 26. Nyo Nyo K, Zaw KK, Naing KK. The economics of tobacco control in Myanmar. HNP Discussion Paper, Economics of Tobacco Control Paper No. 14. Washington DC:World Bank, 2003.

27. Isra $S$ et al. The economics of tobacco in Thailand. HNP Discussion Paper, Economics of Tobacco Control Paper No 15. Washington DC: World Bank, 2003.

28. Lance PM, Akin JS, Dow WH, Loh C. Is cigarette smoking in poorer nations highly sensitive to price? Evidence from Russia and China. Journal of Health Economics 2004; 23:173-189

29. Sayginsoy, Yürekli A, de Beyer J. Cigarrette demand, taxation and the poor: a cause study of Bulgaria. California: Center for Tobacco Control Research and Education, 2002.

30.Van Walbeek C. The distributional impact of tobacco excise increases. S Afr J Econ 2002; 70(3):560-578.

31. Laxminarayan R, Deolalikar A. Tobacco initiation, cessation and change: Evidence from Vietnam. Health Econ 2004; I3(I2): I I9I-I20I.

32. Da Costa e Silva VL, Goldfard MM, Turci SRB, eds. Brazilian cigarettes: Analysis and proposals to reduce consumption [Portuguese]. Rio De Janeiro: INCA/CONPREV, 1999.

33. Tobacco control country profiles. Atlanta, GA:American Cancer Society; 2000. Available in: http://wwwl.worldbank.org/tobacco/ countrybrief.asp)

34. Ranson K, Jha P, Chaloupka F], Yurekli A. Effectiveness and costeffectiveness of price increases and other tobacco control policies. In: Jha P, Chaloupka FJ, eds. Tobacco control in developing countries. Oxford: Oxford University Press, 2000:427-447. 
35. Kenkel D, Chen L. Consumer information and tobacco use. In: Jha P, Chaloupka FJ, eds. Tobacco control in developing countries. Oxford: Oxford University Press, 2000:177-2I4.

36. Woolery T, Asma S, Sharp D. Clean indoor-air laws and youth access. In: Jha P, Chaloupka FJ, eds. Tobacco control in developing countries. Oxford: Oxford University Press, 2000:273-286.

37. Sansores RH, Giraldo-Buitrago F,Valdelamar-Vazquez F, RamirezVenegas A. The impact of mass media on an anti-tobacco campaign. Salud Publica Méx 2002;44 Suppl I:SI0I-108.

38. Warner KE, Slade J, Sweanor DT.The emerging market for long-term nicotine maintenance. JAMA 1997; 278: 1087-1092.

39. Warner KE, Fulton GA, Nicolas P, Grimes DR. Employment implications of declining tobacco product sales for the regional economies of the United States. JAMA 1996: 275; 124I-6.

40. Jacobs R, Gale F, Capehart T, Zhang P, Jha P. The supply-side effects of tobacco control policies. In: Jha P and Chaloupka FJ, eds. Tobacco control in developing countries. Oxford: Oxford University Press, 2000:3 I I-34I.
4I. Sunley EM, Yurekli A, Chaloupka FJ. The design, administration and potential revenue of tobacco excises. In: Jha P, Chaloupka FJ, eds. Tobacco Control in developing countries. Oxford: Oxford University Press, 2000:409-426.

42. A win-win: Enhancing public health and public revenue.

Canada:Canadian Coalition For Action on Tobacco, January 2004.

43. Saxenian H, McGreevey B. China: Issues and options in health financing. World Bank Report No. 15278-CHA. Washington DC:World Bank, 1996.

44. Merriman D, Chaloupka FJ, Yurekli A. How big is the worldwide cigarette smuggling problem? In: Jha P, Chaloupka FJ, eds. Tobacco control in developing countries. Oxford: Oxford University Press, 2000:365-392.

45. Warner KE. The economics of tobacco: myths and realities. Tobacco control 2000; 9:78-89.

46. Joossens L, Raw M. Smuggling and cross-border shopping of tobacco in Europe. BMJ 1995; 310:1393-1397

47. Hu T, Mao Z, Liu Y, de Beyer J, Ong M. Smoking, standard of living, and poverty in China. Tob Control 2005; 14:247-250. 